Purdue University

Purdue e-Pubs

Charleston Library Conference

\title{
Reimagining Research Services as Part of Major Academic Library Renovations or Other Changes: A Tale of Two Research Departments (University of Central Florida and Florida Gulf Coast University)
}

\author{
Barbara G. Tierney \\ University of Central Florida Libraries, barbara.tierney@ucf.edu \\ Linda Colding \\ Florida Gulf Coast University Library, lcolding@fgcu.edu
}

Author ORCID Identifier: https://orcid.org/0000-0002-1145-1566

Follow this and additional works at: https://docs.lib.purdue.edu/charleston

Part of the Library and Information Science Commons

An indexed, print copy of the Proceedings is also available for purchase at:

http://www.thepress.purdue.edu/series/charleston.

You may also be interested in the new series, Charleston Insights in Library, Archival, and Information Sciences. Find out more at: http://www.thepress.purdue.edu/series/charleston-insights-library-archivaland-information-sciences.

Barbara G. Tierney and Linda Colding, "Reimagining Research Services as Part of Major Academic Library Renovations or Other Changes: A Tale of Two Research Departments (University of Central Florida and Florida Gulf Coast University)" (2017). Proceedings of the Charleston Library Conference.

http://dx.doi.org/10.5703/1288284316667

This document has been made available through Purdue e-Pubs, a service of the Purdue University Libraries. Please contact epubs@purdue.edu for additional information. 


\title{
Reimagining Research Services as Part of Major Academic Library Renovations or Other Changes: A Tale of Two Research Departments (University of Central Florida and Florida Gulf Coast University)
}

\author{
Barbara G. Tierney, University of Central Florida Libraries \\ Linda Colding, Florida Gulf Coast University Library
}

\begin{abstract}
Two academic library research service managers discuss changes and innovations that they have coordinated in their respective libraries: University of Central Florida serving 60,000+ students (http://library.ucf.edu/21st/) and Florida Gulf Coast University serving 15,000+ students (http://library.fgcu.edu/admin/renewal.html) due to major building renovations or other changes that their respective libraries are conducting.

These changes and innovations include significantly downsizing print reference and other collections, relocating service points, reconfiguring public services, rethinking staffing patterns, adjusting subject librarian face-to-face activities, stepping up online services, communicating with stakeholders, and keeping students and faculty in the loop so that their voices are heard and their needs met.
\end{abstract}

\section{UCF Libraries Overview}

The University of Central Florida (UCF) is a research university that serves more than 66,000 students, making it one of the largest universities in the nation. UCF is home to 13 colleges that offer over 200 majors. It offers 95 bachelor's, 86 master's, and 31 doctoral degree programs, and ranks first among public universities in the nation for the annual number of baccalaureate degrees awarded and for the number of overall degrees conferred. UCF Libraries' collections include over 1.6 million print volumes. The John C. Hitt Library is UCF's premier library facility and is located on the main (Orlando) campus.

\section{UCF's Building Renovation Plan}

Work on UCF's 21st Century Library Project is well underway. The transformation of the John C. Hitt Library building includes the expansion and complete renovation of all five floors.

Phase One (fall 2016-fall 2017) includes the construction of a four-story Automated Retrieval Center (ARC) on the north side of the Main Library. The ARC will be used to store 1.25 million volumes of the library's print collections. Transferring books into the ARC will free up space for an additional 1,600 user seats and student programming areas.
When completed, the top floor of the ARC will house a beautiful new student reading room. Renovations also will include more group study rooms and graduate student areas, a digital commons, an expanded special collections and exhibits area, and a new main entrance. The renovated library will offer a total of 3,264 seats, compared to current seating for 1,664 .

Along with the completion of the ARC in December 2017, a temporary library entrance will be created, at the ARC side of the existing library's Main Floor, as well as a temporary covered bridge. This temporary entrance and bridge will provide a route through which books and other resources will be transported into the ARC.

\section{How the Building Renovation and Inges- tion of Items Into the ARC Will Affect the Current Main Floor Knowledge Commons Where the Research Services Department Currently Resides}

The plan is to begin the process of ingesting library collections into the ARC from the existing library building in January 2018. When the ingestion begins, there will be a constant caravan of book trucks moving through the student-filled Main Floor Knowledge Commons, past the busy Research Services Desk, the 
Research Consultation cubicles, the Writing Center help cubicle, and student collaborative areas. Even though the book truck wheels will be treated with WD-40, it is anticipated that the movement of collections through the Knowledge Commons will create noise and commotion that will disrupt patron and staff activities.

In addition, the book truck routes through the Knowledge Commons and the creation of construction walls will infringe on space that previously had been devoted to student seating, student collaborative areas, and research service points. It is estimated that the library will temporarily lose a total of 504 seats. To partially compensate for this, the freshly renovated fifth-floor Quiet Reading Room in the existing library will be opened in February 2018 and will add 170 seats.

Also, the RIS Department has been working to significantly downsize the Main Floor print reference collection. Since spring 2017, each subject librarian has been weeding the print reference collection areas within his/her assigned LC call numbers, with a goal of reducing the print reference collection by $75 \%$. Most weeded reference volumes will be moved into the ARC. In the long term, the downsized print reference collection will allow more space for Main Floor student seating.

\section{Beyond WD-40, Ear Plugs, and Aspirin ... Knowledge Commons/Research Services Main Floor Contingency Plans}

What will the Research and Information Services Department do if the 150+ day ingestion process winds up becoming too noisy to conduct reference conversations with patrons at the current Reference Desk or to conduct one-on-one research consultations with patrons in the consultation cubicles adjacent to the Reference Desk? What if the noise is too loud for librarians to conduct the Ask A Librarian virtual reference service within the Main Floor Research and Information Services Department office area, or too noisy for librarians to work in their own offices?

To date, library administration has decided to take a "wait and see approach" with several contingency plans in their back pocket for reconfiguring public services, relocating service points, rethinking staffing patterns, adjusting subject librarian activities, and stepping up online services, if needed.
For example, if needed, library administration is amenable to moving the main Reference Desk service point away from the center of the Knowledge Commons to a desk shared with Circulation Services near the legacy Main Floor library entrance; moving research consultations into the library's enclosed Main Floor classrooms; moving the Ask A Librarian virtual reference service into enclosed office spaces on another floor of the library or for AAL staff to temporarily work out of their homes; moving librarian offices into third-floor Group Study rooms.

\section{Taking UCF's Subject Librarian Outreach Model to a New Level . . . Possibly Out of the Library Altogether}

Since UCF's Subject Librarian program began in spring 2013, the subject librarians increasingly have been acting as their own CEOs with regard to outreach, research consultations, and library instruction. Most subject librarians only are assigned four hours per week of Reference Desk duties, with the rest of the desk slots being assigned to highly trained parttime adjunct librarians.

The subject librarians no longer are tied to the Reference Desk or their library offices, and their cell phones and newly issued lightweight Dell laptop computers are enabling them to be increasingly mobile. Some subject librarian strategies for avoiding the noisy library renovation areas include embracing more online activities (such as increased embedded librarianship, Skyping, online research guides and tutorials) to reach their students and faculty, or getting out of the library altogether and working from other places on campus (such as the Faculty Center for Teaching and Learning or classroom buildings that house their assigned academic programs).

\section{Getting the Word Out About Renovation Matters to Our Constituencies}

With so much change taking place in the library, we know that it is important to keep faculty and students in the loop so that their voices are heard and their needs met during the long renovation period. Some of the communication strategies we are utilizing include conversations with stakeholders at Faculty Library Advisory Board and Student Library Advisory Board meetings, news updates on the libraries' website and social media outlets, 
signage on whiteboards at the library entrance and in the library elevators, "Installments Newsletters" in library restroom stalls, subject librarian newsletters and e-mails to academic departments, Research Guides, announcements at library instruction classes and workshops, and print flyers at service desks.

\section{Next Phase of the Renovation Project}

The next phase of the renovation project will be constructing the connector building between the ARC and the existing library building, which will begin in early 2018 and be completed in early 2019. When all renovations have been completed, the current three-sided Reference Desk will be replaced by a much smaller reference service point probably located at the same place where the current desk is situated. This new service point will be staffed primarily by highly trained part-time adjunct librarians and paraprofessionals. In addition, all Research Services Department librarian offices will be moved to the third floor, and the space that the offices had occupied will be converted into student collaborative areas.

\section{FGCU and Library Background}

As you drive on the campus of Florida Gulf Coast University in Fort Myers, Florida, you will see a large sign saying, "It started with Land and a Grand Plan." This summarizes the 20-year history of our university. In 1991, the Florida Board of Regents recognized there was no state university serving Southwest Florida. Soon afterward, the governor signed legislation authorizing the tenth state university. Our first student was admitted in 1997 and a year later, the first commencement ceremony was held.

Today we are a teaching university with $80 \%$ of our classes being taught by full-time faculty. We have around 15,000 students representing 45 states and 85 countries. We have 54 undergraduate, 23 graduate, and 3 doctoral programs. In the past academic year, the top three awarded degrees were Resort Management, Psychology, and Mass Communication.

The library began as a two-story building. For \$1 million, we purchased the library collection of a New Jersey college that was closing. In 2006, an additional wing with four floors was built. However, the fourth floor does not belong to the library and houses classrooms and faculty offices. Today, we have nearly 135,000 square feet. My department, the Reference,
Research and Instruction Department, is home to seven subject librarians, an instructional technology librarian, and an instructional support specialist. I was the first person hired specifically as the department head.

\section{Collection Analysis Project (CAP)}

As you might expect, the original collection continued to grow and expand. After 17 years, we decided it was time to evaluate the collection. We had two goals in mind. First, we wanted to review how the collection was used to ensure our users had the right materials to support their educational and research needs. We also needed to respond to changing space requirements.

To accomplish this evaluation, in 2014, we began the Collection Analysis Project. Subject librarians would use their subject expertise and program familiarity to identify items that still had merit and flag those items that were no longer needed. Our Collection Management staff prepared detailed reports, which provided the librarians with information such as when an item was added to the collection, if it had circulated in the past five years, and its format.

Throughout the project, subject librarians continued working with faculty to assure them nothing would be removed from the collection that was critical to their research and teaching. Our dean also assured faculty that if something was removed by mistake, we would purchase it again.

\section{How the CAP Worked}

The CAP was performed over a two-and-a-half-year period with collection evaluations overlapping. Over a two-month period, the VHS collection was reviewed. Because $82 \%$ had never circulated, we were confident in removing most of it and replacing the others with streaming videos. Since the DVD/ CD collection was very small, it only took two weeks to review. The next area was periodicals, which took about six months to review. Over the years we had switched many of our subscriptions to electronic versions, causing the print growth rate to slow to where we could consolidate two floors of bound periodicals onto one floor. The reference collection also took six months to review. During this review, our subject librarians determined if books would remain in reference, be moved to the general collection for circulation, be transferred to remote storage, or be 
completely removed from the library. The review of the microform collection was completed in stages over a year. The final collection to be reviewed was the general collection. During this review, which took 11 months, the subject librarians determined if the books would remain in the general collection for circulation, be transferred to remote storage, or be completely removed from the library.

With one final sweep of the reference collection, the review was complete. We were able to consolidate and make a much smaller reference collection. The general collection also had to be shifted and consolidated to accommodate the additional reference materials.

\section{Mission Accomplished}

Our mission was accomplished. We had reviewed the collection to ensure it met the educational and research needs of our students and faculty. Overall, we removed $21 \%$ of the collection. Specifically, we removed $60 \%$ of the reference collection and an additional $12 \%$ was moved to the general collection. That's an overall reduction of $72 \%$ of the reference collection. Our microform cabinets were reduced from 50 cabinets to 18 , which were moved out of the public area into Technical Services.

With all of these reductions, we opened plenty of space to create more student learning spaces. With end-of-year funding from the provost, we have been able to make an initial purchase of new furniture. The new furniture will create an area for students to work collaboratively or individually and create private spaces for subject librarians to conduct research consultations.

\section{Library Next: A Campus Conversation}

This project was more than just an analysis of our collection and opening spaces. It gave us the opportunity to reimagine the services we could offer. Therefore, we gave the entire project a more appropriate name, Library Next.

During the CAP, we wanted input from our students and faculty. A university-wide conversation was held, which we called "Library Next: A Campus Conversation." Librarians served as facilitators at student tables as well as faculty and staff tables. From the students, we wanted to know how the library could support their need for a quiet place for study while at the same time providing space to engage interactively. Another area was finding out what we could do to help with student retention. We questioned if collaborating with other services, such as the Writing Center and the Center for Academic Achievement, could help retain students. Finally, we wanted to know what additional software or hardware was needed to support student learning. From the faculty and staff, we wanted information about instruction. The subject librarians were already using an integrated approach to teaching and assessing information literacy. We also wanted to find out what the library could do to make our virtual and electronic collections easier for faculty to integrate into their courses.

\section{Learning Commons Task Force}

We also initiated an internal task force made up of library faculty and staff. The task force was charged with making recommendations on creating a learning commons. Along with information gleaned from the Campus Conversation, the task force surveyed the literature and interviewed leaders in the learning commons field. Their recommendations were made to the dean and the entire library faculty earlier this year.

\section{Where We Are Today}

Since the inception of Library Next, the subject librarians have continued providing research and instruction services. Staffing was an issue that needed to be addressed. There was not a health sciences librarian or an instructional support specialist. In addition, there had not been a department head in a year. Hiring people to fill those positions was important to extending our services.

With a fully staffed department, our librarians only needed to staff the Reference Desk about four to five hours a week. Librarians from other departments and part-time librarians staff the remaining desk hours. With less time on the desk, subject librarians are able to put more emphasis on our virtual reference services. Less desk time also means more time for research consultations.

A Mobile Librarian service was initiated. This program provides service at the point of need. Everyone in the library who was interested could participate. With tablets, we walk around the library looking for students in need. This year we added a mobile podium, which serves as a focus point for the 
service. Students are directed to the podium from other service points.

The subject librarians have also worked with faculty to integrate their Research Guides into Canvas, our learning management system. With this addition, students have access to a research starting point as well as immediate access to their subject librarian.

From the Campus Conversation we learned how collaborating with other services could assist our students. As the collections shifted and space opened, we created the Hub, an area where our Center for Academic Achievement could hold tutoring sessions. We have also partnered with the Writing Center to hold drop-in research clinics.

Another result of the Campus Conversation was a media production area. With more space, we were able to provide an area for this much-needed service. Collaborating with the campus radio station and Communication Department, we now house equipment for students to create podcasts and other media activities. Recently, the student government approved additional funding for more professional equipment and acoustic paneling and curtains for sound absorption.

\section{Conclusions}

Two 21st-century academic library Research Service departments serving differently sized student populations are working to achieve better use of space within their respective service areas by weeding their print collections to free up room for student seating and programming activities.

Each Research Service Department also is rethinking its service desk staffing model (using software programs to collect and analyze user activity and inform staffing decisions) and following a strategy of hiring part-time librarians to staff the Reference Desk, in order to reduce the number of hours that their subject librarians are tied to a service desk. This strategy allows the subject librarians more time for outreach, instruction, research consultations, collection development, research guide creation, and programming.

Many other possible changes have been placed on the table for consideration, including further reconfiguration and relocation of service points and stepping up online services. Both libraries realize the importance of communicating with stakeholders and keeping students and faculty in the loop so that their voices are heard and their needs are met each step of the way.

\section{References}

Florida Gulf Coast University. The Library NEXT Project. Retrieved November 29, 2017 from http://library.fgcu.edu /admin/renewal.html

University of Central Florida Libraries. 21st Century Library. Retrieved November 29, 2017 from https://library.ucf .edu/21st/ 